\title{
MANAGEMENT OF A PHYSIOTHERAPY DEPARTMENT
}

\author{
CAROL CORNELL, Dip. Physio. (Cape Town)*
}

\begin{abstract}
The concept of scientific management is considered. The functions of management are defined and discussed with particular reference to the management of a physiotherapy department. Qualities which are required in a supervisor are examined and the necessity for the development of management skills is stressed. The shortage of formally trained physiotherapy managers is noted and possible solutions to remedy this problem are suggested.
\end{abstract}

Managing a physiotherapy department can be exciting and challenging but how many physiotherapists have the ecessary skills to do full justice to the position? Tradiionally medical and paramedical services are headed by members of their particular professions. Usually these department heads have had no formal managerial training and while experience is valuable, it should be an adjunct to and not a replacement for management knowhow. Hospitals and their component departments need skilled administrative and clinical supervision to ensure an efficient health care service. Therefore it is essential that managerial skill should be as much part of a physiotherapist-in-charge's job as clinical skill.

This article is geared towards the physiotherapist working for a Provincial or Government authority or other large corporation rather than for someone who is self-employed. However, the basic principles of management discussed are applicable to any situation.

Scientific management - a term now in general use is a fairly new discipline but has developed rapidly throughout the modern industrial world in recent years. Our ever more complex environment makes demands on us which can only be solved by the development of new skills. These skills are applicable to all fields of human endeavour from household management to the running of a physiotherapy department.

A definition of management is not easy but the following is a good working definition: The process by

Private Practitioner; formerly Principal Physiotherapist, Day Hospitals Organisation, Bellville.

Received 30 April 1980.

\section{OPSOMMING}

Die konsep van wetenskaplike bestuur word oorweeg. Die funksies van bestuur met spesiale verwysing na die bestuur van 'n fisioterapie-departement word gedefinieer en bespreek. Eienskappe nodig vir toesighouers word ondersoek en die behoefte vir die ontwikkeling van bestutursvaardighede word beklemtoon. Daar word gelet op die tekort aan formele opleiding van fisioterapiebestuurders en moontlike oplossings hiervoor word voorgestel.

which the senior staff of any group directs actions towards a common goal. Implicit in this definition is the understanding that managers themselves seldom carry out the activities; rather they delegate duties to and supervise their efficient discharge by other people.

\section{FUNCTIONS OF MANAGEMENT}

It must be stressed that management is an integrated concept and it is difficult to divide it into separate functions. However, it is a useful exercise to undertake if merely to try and underline the full scope of the discipline. Joseph L. Massie (1971) defines the following seven functions of management:

Decision making - the process by which a course of action is consciously chosen from available alternatives for the purpose of achieving a desired result.

Organizing - the process by which the structure and allocation of jobs is determined.

Staffing - the process by which managers select, train, promote and retire subordinates.

Planning - the process by which a manager anticipates the future and discovers alternative courses of action open to him.

Controlling - the process that measures current performance and guides it towards some predetermined goal.

Communicating - the process by which ideas are transmitted to others for the purpose of effecting a desired result.

Directing - the process by which actual performance of subordinates is guided towards common goals.

On reading the above list, two things come to mind.

\section{Contents - Inhoud}

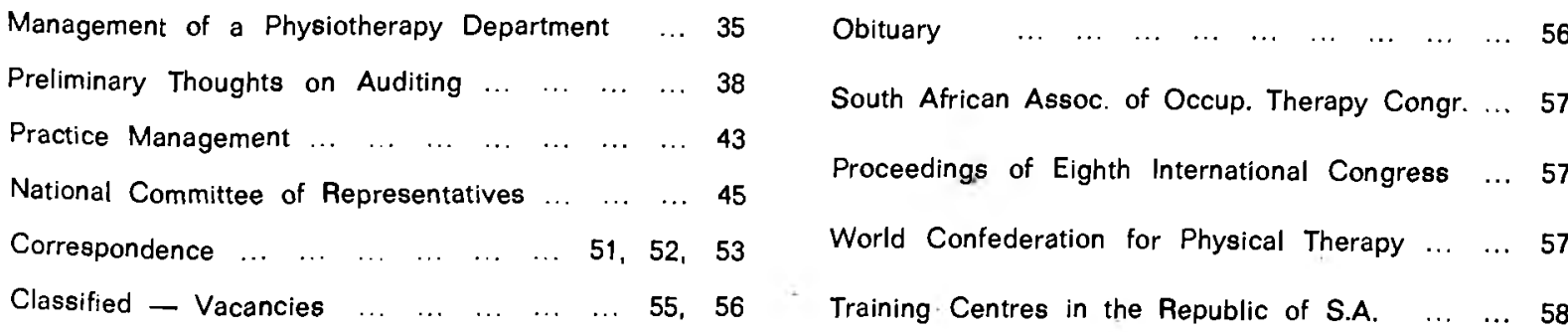


Firstly, most of the points could be described as commonsense but the consistent application of so-called commonsense is rare. Secondly, many of the functions overlap; for example, staff motivation would combine the functions of directing and staffing, thus re-emphasizing the integrated nature of the process.

Since management has been defined and dissected, what of the characteristics of the good manager? Robert Katz (1955) sums these up in the following points:

The good manager requires:

Technical skills, i.e. proficiency in performing an activity in the correct manner with the appropriate techniques;

liuman relationship skills - the skill of co-operating with others.

Conceptual ability - the ability to see individual matters as they relate to the overail picture.

Having outlined the scope of management, let us now consider how this relates to some practical points concerning the supervision of a physiotherapy department. As mentioned above, it is well nigh impossible to separate the various functions of management so there will be some overlap.

\section{Decision and Policy Making}

Physiotherapy departments, in common with, other hospital departments, usually have to work within the constraints of overall hospital policy (a policy being a guideline for decision-making). The first thing a head of department must do is to become thoroughly familiar with this policy so that the aims of the department may mesh smoothly with those of the hospital. It is often useful to gain the ear of a helpful administrative officer who can explain the finer details and iron out misunderstandings.

Decision-making is a whole subject on its own. For the purposes of this article, suffice to say that decisions may be made by individuals, by formal committees or by informal groups and no one method is right all the time. time.

\section{Organizing}

One of the most important facets of organizing is the careful drawing up of job descriptions, the benefits of which are numerous. The compilation of a job description for each member of staff requires careful planning but it does supply a yardstick by which the performance of the department and the individual concerned may be judged. The job description is a concise summary of the duties and responsibilities of the particular job and it serves as a useful communication tool and problemsolving device as, should problems arise, it provides a framework within which a solution can be found. The members of staff should be actively involved in compiling the description. Not only are they the people filling the jobs but this approach also gives them the opportunity to contribute towards the management of the deparment which, in turn, engenders a feeling of belonging and participation. The members of staff know what will be required of them and they too have something concrete by which to assess their own progress. Remember, however, that any situation involving people is dynamic and not static and regular updating of the job description may be necessary.

\section{Planning, Staffing, Cop̣trolling, Directing}

The current physiotherapy staff shortages and the limitation of the executive powers of the supervisor in many institutions does curtail management function. This fact notwithstanding, because management must plan for both the present and the future, the following points should be borne in mind and implemented where possible.

Besides clinical notes, records of all aspects of departmental function are vital. On these facts and figures will hinge the response from the hospital administrators to requests for additional staff, building alterations, new equipment and improved conditions of service. Future planning is impossible without access to such records. In addition, hospital administration does demand, from time to time, information to justify aspects of the department's function on an economic basis. Equally important, the supervisor must know how to present this information in well-motivated and succinct memoranda.

Where possible, direct involvement in the planning of any new department is essential. Regretfully all too frequently the supervisor who should be consulted regarding the building requirements is only brought in at a late stage. Where such an opportunity does present itself, careful consideration must be given to the many factors involved, such as the type of service required, equipment needed, the demands which may be made by popu lation growth and many other factors which go beyond the scope of this article. Consultation with other physiotherapy supervisors in the area or further afield, if necessary, is a useful means of gaining additional information.

The provision of an adequate staff to cope with the workload must be ensured. On-going evaluation of the function of the department and the demands made on it must be carried out on a regular basis. On the basis of these findings, the service must accordingly be pruned or extended.

It is a waste of professional skill to have tasks carried out by qualified staff which could be done satisfactorily by unskilled staff. Provision should be made for the allocation of such supportive personnel to the staff establishment, their role being to maintain the productivity of the physiotherapy staff at an optimum level. O'Neill (1976) states that as a general rule, in the general hospital departments investigated for their report, where there was a staff of three or more, approximately one third of the staff was non-physiotherapist.

Where a physiotherapist is sole-in-charge, the appointment of an aide/receptionist to the department is essential if productivity is not to suffer. All too often this is the very situation where a physiotherapist is assured that, if help is needed, she need only ask a nurse aide or porter. Inevitably, this unspecified help is not readily available when required. The result is tension betwee personnel and valuable patient treatment time is lost.

Delegation of duties and responsibility by the supervisor is essential for the smooth running of the bigger department. Marcus (1966) in his article on common failings of supervisors describes the "seven deadly sins", one of which is: "Playing everything close to the chest. Keep everything to yourself. Don't tell anybody anything . . Just be uncommunicative". The result is usually inefficiency and an unhappy department.

Part of the process of control is provision for evaluation of staff performance, particularly of the new staff member. The staff need to know clearly what is expected of them; this is provided by the job description previously discussed. Satisfactory work should be given recognition and poor work should be constructively criticised. A specially designed evaluation form should be used.

\section{Communication}

Communication provides the link between all other functions. The types of communication in an organisation can be described as vertical, flowing back and forth between managers and subordinates; horizontal, where staff on same level co-ordinate activities without refer- 
ence to their superior; informal, e.g. the "grapevine".

Effective communication is regular communication. The supervisor must relay information from the department to the hospital administration and must in turn relay relevant information back to the department. Systems must be set up within the department to encourage a flow of information between staff, and to anticipate and solve problems. Important matters should be written; written requests deserve written replies. Oral messages may be in order at times but the more levels they have to go through, the more room there is for error.

Conflict is an inherent part of management and may be handled by (1) domination, (2) compromise, or (3) integration. Integration would seem to be the most successful approach.

To achieve it, differences must be brought into the open, all parties concerned join in the discussion and together a position acceptable to all and to their working relationships is chosen.

To encourage communication within the physiotherapy stablishment, regular staff meetings are a must. These gatherings serve both as an opportunity for clinical teaching and for administrative discussion and instruction,

A further practical point in this field: never take it for granted that other hospital personnel know either the whereabouts of the staff at any given time or the details of the department's working hours. This is particularly pertinent for the busy supervisor or the physiotherapist in the sole-in-charge situation. Always ensure that any variation in the routine physiotherapy service offered, and hence expected by other departments, is documented and circulated to relevant sections. Do not forget to notify the physiotherapy staff of changes as well. Many physiotherapy jobs entail a great deal of mobility during the day. It is therefore essential that a receptionist be available at all times to process enquiries, thereby facilitating the smooth running of the department.

A useful routine for the supervisor is to organize a set period daily when staff queries can be dealt with on a personal basis. Nothing alienates both other hospital staff and the physiotherapists themselves more quickly than the constantly elusive and apparently too busy supervisor.

At the clinical level, good communication must be maintained between the physiotherapy department and other departments of the hospital. By means of conltation with relevant department heads, the role which we physiotherapists are expected to fulfil must be clearly defined. Each physiotherapist should be encouraged to participate fully in the health team activities of their section. Attendance at clinical meetings and ward rounds provides good opportunities for the physiotherapist to learn and to contribute. It should also be stressed to staff that they must as a matter of routine, report back to the doctors regarding patients' treatment progress. This is something which is often neglected.

As mentioned briefly, under planning, it is advisable for a supervisor to keep in contact with heads of other physiotherapy departments. It provides an opportunity to share knowledge, get advice and discuss common problems when the need arises.

Not least, good rapport must be fostered between the staff and their patients and extended to the patient's family if they are available for consultation. As the physiotherapist is so often in a counselling situation, it is advisable for special attention to be given to this field during training sessions.

\section{The Supervisor}

The supervisor is in fact a leader and the type of leadership chosen will set the tone for the department.
The dictatorial approach - "do it or else" is to be avoided as is the paternilistic type of leader who does everything personally, thereby making their staff reliant on them. The leader should develop the democratic approach, where he/she depends not only on his/her own abilities but actively encourage his/her subordinates to accept responsibility and participate in decision-making and planning. By these means both personal growth and the development of managerial ability is encouraged. This approach builds up a co-operative attitude and job satisfaction amongst the group towards the job.

The supervisor needs to be people-conscious; personnel management is a vital part of the job. An openminded, outward-looking approach should be developed and any tendency towards a rigid attitude should be checked. The staff have the right to expect a firm yet fair and considerate approach. If the supervisor does not know something, or has made a mistake, it should be admitted since nobody will be fooled by an attempt to hide the fact.

Continuous education is essential and attendance of all staff at post-graduate courses should be both expected and actively promoted.

The supervisor should be a member of the professional society and take an active role in its activities and encourage staff to do the same.

When applying for such a post, the prospective supervisor should realise that managerial skills, if not yet acquired, will have to be developed. This will enable them to cope with the complexities of administration and thereby ensure efficient and effective patient care. Also to be borne in mind is that the appointee to such a post will be required to represent the profession to the administration. Such a challenge should be met with enthusiasm.

\section{CONCLUSION}

Various aspects of management and their application to physiotherapy have been considered. The need for such skills in today's environment has also been discussed. However, where can the physiotherapist get formal managerial training? At present, none of the physiotherapy training centres offers such a course. Perhaps it is worth considering the introduction at undergraduate level of a course in basic management which could then serve as a foundation for the practical experience gained later, while working. Various branches of the South African Society of Physiotherapy have organized lectures touching on aspects of management and this is to be encouraged. There is a great deal of literature available on the subject and articles have been published specifically on physiotherapy management by some overseas physiotherapy journals.

The managerial process is a complex social activity and the idea that management is something related to business and not to a professional role must be refuted. Management supplies a framework for the efficient and consistent running of any organization, be it large or small, professional or non-professional.

\section{References}

1. Katz, Robert L. (1955). Skills of an effective administrator. Harvard Business Review, Jan-Feb 33 - 42.

2. Marcus, Edward $\mathbf{E}$. (1966). The physical therapist in supervision. Phys. Ther. 46, 391-394.

3. Massie, Joseph L. (1971). Essentials of Management, 2nd Ed. Englewood Cliffs N.J. Prentice Hall.

4. O'Niell, Michaela T. (1976). Physiotherapist caseload standards. Physiother. Can. 28, 95-98. 


\section{Bibiliography}

Feitelberg, Samuel B. (1966). Basic considerations of a job description. Phys. Ther. 46, 383-386. 386.

Lister, Marilyn J. (1966). Performance evaluation of the new staff member. Phys. Ther. 46, 387-390. 387-390.
Rochelle, Donna (1966). How to answer questions. Phys. Ther. 46, 428.

Todd, J. W. (1977). The use of hospitals. 6 Analyses. Update, April, 935-938.

Kenly, Judith D. (1972). A supervisor's view of staff evaluation. S. Afr. J. Physiother. 28, 2-4.

Whitfield, A. G. (1978). Chair a committee. Br. Med. J. 2, 936-937.

\title{
PRELIMINARY THOUGHTS ON AUDITING THE EFFICIENCY OF A PHYSIOTHERAPY SERVICE USING A GOMPUTER PROGRAMME
}

\author{
M. J. RUNNalls, Dip. Physio., C.T.P. (Cape Town)*
}

\begin{abstract}
The initiation of a documentation audit of the efficiency of physiotherapy services provided in a large general teaching hospital is discussed. Results and trends of behaviour as analysed by computer programmes are shown.
\end{abstract}

\section{INTRODUCTION}

The Tygerberg Hospital is not only a large general teaching hospital but also part of a large provincial hospital (state controlled) organisation. Thus, because of its very size (1 750 beds) and the hierarchy in the managerial system there will naturally be certain intrinsic problems. To be confident that there is an adequate physiotherapy service in both out-patient department and wards is not easy. It is also well nigh impossible for the senior physiotherapy staff to keep track of all that occurs. The fact that a junior or even a senior member of staff, is unhappy, or perhaps inadequate as regards their work potential and capacity can go unnoticed. It is also difficult to defend the department against just or unjust criticism from higher authorities, the medical profession, nursing profession, other allied health services and peers unless its effectiveness (the case) can be substantiated very clearly. Furthermore, it should be remembered that litigation will inevitably become more prevalent and substantiative evidence again will be essential to defend the case.

\section{METHOD}

With these problems in mind a documentation audit has been instituted based on the work of Khan and Howroyd (1976) who posed the following questions:

1. Is an acceptable standard of care being provided?

2. Does the present standard of care show any improvement over previous years?

3. Is the staff competent?

4. Is full use of resources being made?

Auditing of documentation becomes a way of assessing the efficiency of the department. Fully realizing that this is purely a "documentation" audit it can, however, be regarded as a relevant and reasonable measurement of efficiency of the services provided. Such an audit can

* Senior Lecturer and Head of Department of Physiotherapy, University of Stellenbosch and Tygerberg Hospital.

Received 30 April 1980.

\section{OPSOMMING}

Die instelling van' $n$ dokumentasie-oudit van die doeltreffendheid van fisioterapie-dienste wat in 'n groot opleidingshospital voorsien word, word bespreek. Resultate en gedragspatrone soos deur rekenaar-programme ontleed, word aangedui.

be evolved around two focal points, and the Problem Oriented Medical Record approach propagated by Weed (1968, 1971). The two focal points are:

1. The physiotherapist viz. the measurement of professional competency and

2. the system viz. the identification of problems which limit the system and thus the competency of the physiotherapist.

With regard to the physiotherapist there are four characteristics of professional competency which can be analysed:

1. Completeness: Are all the data fully recorded? Are all the problems identified? Are there plans pertaining to all the problems?

2. Reliability: Are the data accurate? Are all the data kept up to date? Are all the plans instituted? Is there evidence that the latest treatment modalities are being implemented?

3. Sound analytical sense: Is there evidence that th data obtained are used to solve the problems? 1 . the plan that has been developed relevant to the data? Does the plan take cognisance of the latest treatment techniques? Are all the plans realistic?

4. Efficiency: Are the problems solved within a reasonable amount of time? Are alternative treatment methods implemented when necessary and as soon as possible?

A documentation audit that would fulfil all the abovementioned factors with certain measurable criteria had to be established. For this purpose audit forms for longterm patients (hospitalization of more than 14 days) and and short-term patients (hospitalization of less than 14 days) were evolved. These forms were drawn up so that the results could be computerized and were based on the form proposed by Khan and Howroyd (1976). (Figs. 1 and 2). A short computer programme was written to calculate the percentages for each sub-section of the audit form. These percentages were then used for furthere analyses. By means of the BMDP9D programme of the BMD programme package a monthly analysis of efficiency was possible. Further computer programmes were set up to show the trends of behaviour in the various sub-sections of the established criteria for efficiency as well as to establish auditor bias. 